\title{
RESPONSE
}

\section{THE RECONGILIATION OF RETIREMENT SEGURITY AND TAX POLICIES: A RESPONSE TO PROFESSOR GRAETZ}

\author{
Nancy J. Altman $\dagger$
}

\section{INTRODUCTION}

Over the last few years, policymakers have urged experts to analyze comprehensively the nation's retirement programs and policies. ${ }^{1}$ Professor Michael Graetz's recent article, The Troubled Marriage of Retirement Security and Tax Policies, ${ }^{2}$ is an effort in this direction. In that article, Professor Graetz admirably seeks to address the three major components of our retirement income system-Social Security, taxqualified private pensions, and individual savings-as a unified whole. Unfortunately, he examines the retirement income system solely from the perspective of tax policy. This limited focus leads him to find fault with fundamental aspects of the system that are readily justified when a broader, more comprehensive perspective is employed. In the name of tax equity, he proposes solutions that would inadvertently undermine important strengths of the current system of providing retirement income. At the same time, he discounts or overlooks alternative solutions

† Lecturer in Public Policy, Kennedy School of Government, Harvard University. A.B. 1971, Radcliffe College; J.D. 1974, University of Pennsylvania. The author thanks Ira C. Lupu and Robert J. Myers for their valuable comments on an earlier version of this Response.

${ }_{1}$ See, e.g., Ross, Private Sector Retirement Security: The Need for a Comprehensive National Income Security Policy, in PrIVAte Sector Retirement aNd U.S. TAX PoliCY 5 (1984) (observing that private pension plan issues are usually analyzed solely from the perspective of federal tax policy and expressing the need for a more comprehensive viewpoint, which includes public sector programs as well); see also $R e-$ tirement Income Security in the United States: Hearings Before the Subcomm. on Social Security and the Subcomm. on Oversight of the House Comm. on Ways and Means, 99th Cong., 1st Sess. 92 (1985) (statement by Rep. Bill Archer expressing concern that Social Security and private pension legislation have been enacted in the absence of a coordinated and consistent policy).

2135 U. PA. L. REv. 851 (1987) [hereinafter Graetz]. 
that would alleviate his tax equity concerns in a manner more consistent with broader income security goals.

Part I of this Response expands upon Professor Graetz's observation concerning the value of examining our retirement income system as a unitary whole. Part II challenges his proposals to change the Social Security payroll tax. It argues that in his quest for tax justice, Professor Graetz ignores those attributes of Social Security that underpin its political support. This political support provides the program with the long-term stability essential to the successful maintenance of any program of retirement income. Part II concludes with a set of alternative proposals that seek to reconcile his concerns with those essential attributes of Social Security. Finally, Part III discusses Professor Graetz's objections to tax subsidies for the promotion of voluntary, employersponsored private pensions. Part III then defends the use of tax expenditures for that purpose.

\section{The Value of Comprehensive Analyses of the Nation's RETIREMENT INCOME SYSTEM}

Retirement income in this country is generated from a variety of public, private, and publicly-encouraged private sources. Our primary public retirement program is the old-age and survivors portion of Social Security. ${ }^{3}$ Most federal, state, and local employees participate in pension plans, financed mainly from public revenue. ${ }^{4}$ The federal government also provides retirement support to low-income people over age sixty-five through a variety of means-tested programs, ${ }^{5}$ such as the Supplemental Security Income ("SSI") program ${ }^{6}$ and the Food Stamp program. $^{7}$

s See 42 U.S.C. $\S \S 401-33$ (1982 \& Supp. III 1985 \& West Supp. 1987). For a detailed description of Social Security, see R. MYERS, Social SecurITy 3-708 (3d ed. 1985).

Many public retirement programs require employee contributions as well. For a discussion of federal, state, and local retirement plans, see R. MYERS, supra note 3, at 923-52. See also E. Andrews, The Ghanging Profile of Pensions 10-11, 33-39 (1985) (discussing government-employer pension plans, including the civil service retirement system and state and local plans). In addition to these public programs, approximately 400,000 railroad employees are covered under a railroad retirement system that is federally managed but financed by railroad employers and employees. For a description of the railroad retirement system, see R. MYERS, supra note 3, at 769-819.

- A "means-tested" assistance program is one for which the payments are determined strictly on the basis of the recipient's means. The payment amounts are generally reduced to compensate for other income. See R. MYERS, supra note 3, at 713.

"Supplemental Security Income for the Blind, Aged and Disabled ("SSI") is a federally financed, means-tested program. See 42 U.S.C. $\$ \S 1381-83$ (1982 \& West Supp. 1987); see generally R. MYERS, supra note 3, at 713-20.

${ }^{2}$ See 7 U.S.C. $\S \S 2011-29$ (1982 \& Supp. III 1985 \& West Supp. 1987). In 
In addition to these public programs, the federal government employs tax subsidies to encourage private employers to provide retirement income to their employees ${ }^{8}$ and, to a more limited extent, to encourage individual savings. ${ }^{9}$ Other tax-favored vehicles, such as the interest deduction for home mortgages, indirectly contribute to security during retirement. ${ }^{10}$ Finally, in addition to the public programs and tax-favored vehicles, some retirement income is generated from nontaxqualified deferred compensation and from ordinary savings. ${ }^{11}$

These various sources of retirement income and the rules and regulations governing them have developed incrementally. ${ }^{12}$ More significantly, these arrangements and the policies associated with them have developed in a compartmentalized, fragmented manner. For example, Congress has traditionally considered Social Security and private pension legislation in separate legislative vehicles, generally in different years, and usually without reference to the impact of the changes on

1984, the Food Stamp program provided benefits to approximately 1.8 million people over age 65. See Senate SPecial Commitree on Aging, Developments in Aging, S. ReP. No. 5, 99th Cong., 1st Sess. 139 (1984). For a discussion of the various cash and in-kind benefit programs providing support to low-income elderly, see EMPLOYEE BENEFIT RESEARCH INSTITUTE, RETIREMENT INCOME OPPORTUNITIES IN AN AgING AMERICA: INCOME LEVELS AND ADEQUACY 20-24 (1982) [hereinafter EBRI]. See also R. MYERS, supra note 3, at 711-68 (discussing the history, development, and current status of public assistance programs including SSI, Medicaid, and Food Stamp).

${ }^{8}$ See I.R.C. $\S \S 401-18$ (1982 \& Supp. III 1985 \& West Supp. 1987); see also President's Tax Proposals to Congress for Fairness, Growth and SimplicITY 375 (1985) [hereinafter PResident's TAX Proposals] (explaining that the rationale for providing favorable tax treatment to qualified retirement plans provided by employers is that such plans "contribute to the national goal of providing security for all retired workers"). For a discussion of what makes the tax treatment favorable, see Altman, Rethinking Retirement Income Policies: Nondiscrimination, Integration, and the Quest for Worker Security, 42 TAx L. REv. 433, 445-46 (1987).

8 Preferential tax treatment is provided, in some circumstances, to individuals who save for retirement through Individual Retirement Accounts or Keogh Plans (for selfemployed persons) and to employees who contribute to employer-sponsored retirement plans. For a description and analysis of these provisions, see Graetz, supra note 2, at 895-902.

10 The deduction of interest on home mortgages has permitted many people to accumulate equity in their homes, increasing their overall wealth, and, if they remain in their homes, reducing their expenses later in life. See EBRI, supra note 7, at 17-18. For a general discussion of income tax incentives that indirectly contribute to retirement security, see Graetz, supra note 2, at 902-04.

11 For a discussion of the tax treatment of nonqualified deferred compensation, see R. Osgood, The Law of Pensions and Profit-Sharing 307-46 (1984). For a discussion of the role of individual savings for retirement, see Altman, supra note 8, at 502.

12 The system and its concomitant rules and regulations have developed gradually over the entire history of this country, with most of the growth occurring during the last fifty years. For a discussion of the history of public and private retirement plans in the United States, together with the development of federal regulations, see W. GREENough \& F. King, Pension Plans and Public Policy 27-77 (1976). 
other parts of the retirement income system. ${ }^{13}$ Four separate congressional subcommittees have jurisdiction over private pension legislation; two other subcommittees have responsibility for Social Security. ${ }^{14}$ Moreover, four different agencies of the federal government have administrative responsibilities for major parts of the retirement income system. ${ }^{15}$

The current concern about the lack of a coherent retirement income policy can be explained not only by the incremental and fragmented manner in which policy has been made, but also by the frequency of changes in recent years. Since 1974, private pension legislation has been enacted in every year except 1977, 1979, and 1983. In two of those latter years-1977 and 1983-major Social Security amendments were enacted. ${ }^{16}$ Moreover, much of the recent pension legislation has been fueled by concerns collateral to the provision of old-

1s For a summary of the Social Security amendments from 1935 to the present, see R. MYERS, supra note 3, at 209-68. For a summary, through 1984, of the primary federal enactments regulating private pensions, see D. MCGill, Fundamentals of Private Pensions 15-55 (5th ed. 1984); E. Patterson, Legal Protection of Private Pension Expectations 85-113 (1960).

14 Jurisdiction over private pension legislation is divided in the House of Representatives between the Subcommittee on Oversight of the Ways and Means Committee and the Subcommittee on Labor-Management Relations of the Education and Labor Committee and in the Senate between the Subcommittee on Private Retirement Plans and Oversight of the Internal Revenue Service of the Finance Committee and the Subcommittee on Labor of the Labor and Human Resources Committee. Social Security legislation is within the jurisdiction of the House Subcommittee on Social Security of the Ways and Means Committee and the Senate Subcommittee on Social Security and Family Policy of the Finance Committee. In addition, both the House Select Committee on Aging and the Senate Special Committee on Aging are charged with studying the problem of retirement income and making recommendations concerning Social Security and pension plans. See Congressional QUarterly InC., Washington InFormaTION DiRECTORY 1987-1988, at 343-44 (1987) [hereinafter DiRECTORY].

${ }^{15}$ The Social Security Administration within the Department of Health and Human Services has primary responsibility for the administration of the Social Security program, although the Secretaries of Treasury and Labor are on the Board of Trustees. The Department of Treasury, the Department of Labor, and the Pension Benefit Guaranty Corporation, a U.S. government corporation, each have partial jurisdiction over the regulation of private pensions. In addition, many other agencies have jurisdiction over aspects of the retirement system. For example, the Equal Employment Opportunity Commission, as a result of its jurisdiction over the Age Discrimination in Employment Act, regulates private pensions with respect to age discrimination. See id. at $152,162-63,343$.

${ }^{16}$ Legislation with respect to private pensions has been enacted in 1975, 1976, $1978,1980,1981,1982,1984,1985,1986$, and 1987. In 1987, Congress enacted the Omnibus Budget Reconciliation Act of 1987, Pub. L. No. 100-203, 101 Stat. 1330. For a list of the enactments through 1986, see Altman, supra note 8, at 508 n.272. Major changes to the old-age and survivors insurance portion of Social Security were enacted in 1977, 1981, and 1983. See Pub. L. No. 95-216, 91 Stat. 1509 (1977); Pub. L. No. 97-35, 95 Stat. 357 (1981); Pub. L. No. 98-21, 97 Stat. 65 (1983). 
age protection. ${ }^{17}$ These factors, together with the large federal cost of these programs, ${ }^{18}$ have contributed to the calls for a comprehensive reassessment of the entire retirement income system.

Given our constitutional system of shared powers among different branches and levels of government, it is understandable that the nation's retirement income policies would have developed incrementally, in a fragmented manner, and without explicit trade-offs among competing and often inconsistent goals. Moreover, incremental decisionmaking has important strengths as a policymaking technique. It tends to respond to real and specific problems. It implements comparatively modest changes that can be tested and reversed if found to have unintended negative consequences. It is flexible and adaptable to changing conditions. At the same time, however, incremental decisionmaking, especially when it is fragmented, may lack coherence, or worse, produce inconsistent results. As a consequence of these weaknesses, scholars who seek to rationalize a set of broad policies and programs can provide important insights for policymakers. ${ }^{19}$ Unfortunately, too many analysts in the retirement income field have limited their inquiries to narrow aspects of a particular retirement program without providing a comprehensive framework within which to assess the system in general and their own critiques in particular. ${ }^{20}$ As Professor Graetz points out, this narrow focus on a particular program or policy has led to conclu-

17 For example, some of the enactments were responsive to budgetary concerns. See, e.g., Omnibus Budget Reconciliation Act of 1981, Pub. L. No. 97-35, tit. XXII, 95 Stat. 357, 830-42 (eliminating, among other things, student benefits and the minimum benefit from the Social Security program). Other recent legislative changes were driven by desires to provide incentives for capital accumulation or stock ownership by workers. See, e.g., Tax Reduction Act of 1975, Pub. L. No. 94-12, 89 Stat. 26 (providing a tax credit for Employee Stock Ownership Plans that satisfied certain conditions).

18 The favorable tax treatment accorded employer-sponsored retirement arrangements constitutes the nation's largest tax expenditure. In 1986, the revenue loss was estimated at approximately $\$ 78$ billion. See Congressional BUdGET OfFice, Tax Expenditures: Current Issues and Five-Year Budget Projections for FisCAL Years 1984-88, at 47, app. A, table A-1 (1983). The old-age and survivors insurance portion of Social Security is the largest domestic spending program. In 1985, it paid benefits of over $\$ 165$ billion. See House Comm. ON WAys and Means, 1986 ANNUAl Report of the BoARd of TRUSTEes of the Federal Old Age and SuRvivors Insurance and Disability Insurance Trust Funds, H.R. Doc. No. 189, 99th Cong., 2d Sess. 17 (1986) [hereinafter Trustens' REPORT].

10 For example, Senator Bill Bradley stated that Professor Stanley Surrey's landmark book on tax expenditures was influential in the Senator's thinking about tax reform. See A Sense of Where He Is, TIME, June 30, 1986, at 37 (referring to S. Surrey, Pathways to TaX Reform: The Concept of Tax Expenditures (1973)).

${ }^{20}$ See, e.g., Roberts, Social Security: Myths and Realities, 3 Cato J. 393, 400-01 (1983) (criticizing the impact taxing Social Security benefits has on other retirement saving without discussing the tax-favored status of much of those other savings). 
sions that turn out to be unwarranted when the program or policy is evaluated in a broader context. ${ }^{21}$

\section{In Defense of the Social Security Payroll Tax}

By focusing on the entire retirement income system, Professor Graetz avoids the tunnel vision he criticizes. He restricts his own vision, however, by looking exclusively through the limiting filter of tax policy. Consequently, he criticizes the regressivity of the Social Security payroll tax and calls for its reform. ${ }^{22}$ Professor Graetz proposes exempting low-income employees from its coverage, at least after they make payments for a minimum number of quarters. ${ }^{23}$ In addition, he urges the elimination of the maximum taxable wage base for tax purposes but not for benefit purposes. ${ }^{24}$ Under this proposal, the highestincome workers would be required to make FICA payments on their entire salaries but would continue to receive the same benefits to which they are entitled under current law.

21 See Graetz, supra note 2, at 852, 871-72 ("Complaints about the unfairness of the social security pension system have become common. . . . [T] ness claim is the failure of social security pensions to replicate . . . an 'actuarially fair' insurance scheme. . . . Viewed from the perspective of overall retirement security, particularly when one considers how income tax expenditures... shape that policy, the real fairness problems [are different]."). Some analysts have criticized Social Security for its unfairness to young, higher income workers. See, e.g., Ferrara, The Prospect of Real Reform, 3 CATO J. 609, 613 (1983) (arguing that the rate of return from Social Security for many younger, higher-income workers will be "practically zero"). This and other rate-of-return calculations are controversial. See, e.g., Myers \& Schobel, $A$ Money's-Worth Analysis of Social Security Retirement Benefits, in TRANSACTIONS 533 (1983) (criticizing other analyses for making inconsistent assumptions, for ignoring certain benefit features, and for using incorrect methodologies). Nevertheless, even if a particular calculation were considered correct, a criticism of the retirement income system on the basis of the rate of return provided by Social Security to higher income workers would be unwarranted in light of the large tax subsidies for private pensions that disproportionately benefit those same workers claimed to be unfairly treated by Social Security.

${ }^{22}$ See Graetz, supra note 2, at 864-74. Social Security is financed through a tax that is levied, under the Federal Insurance Contributions Act ("FICA"), on wages or earnings equal to or below a specified maximum taxable wage base ("covered wages") and are assessed in equal amounts against employers and employees. See I.R.C. $\S \S$ 3101(a), 3111(a) (1982 \& Supp. III 1985). Therefore, the FICA tax is actually proportionate up to the maximum taxable wage base. With respect to wages above and below the wage base, the tax is regressive. It has been pointed out that because the tax is only levied on earned income, it is slightly progressive at the lowest income levels, where some income consists of tax-exempt transfer payments. Moreover, even without the exemption of income above the taxable wage base, the tax might be considered regressive at upper-income levels because higher-income individuals generally have a larger percentage of nonwage income. See J. Pechman, H. Aaron, \& M. Taussig, Social Security: Perspectives for Reform 178-80 (1968) [hereinafter Pechman].

${ }^{23}$ See Graetz, supra note 2 , at $868,906$.

24 See id. at 869-71. 
If Social Security is viewed merely as a transfer program supported by federal taxes, indistinguishable from all other government spending programs, Professor Graetz's argument is compelling. ${ }^{25}$ From a tax equity perspective, a regressive tax is unjustifiable if it fails to take into account ability to pay. ${ }^{26}$ The narrow focus on tax justice, however, overlooks a fundamental point: Social Security is a retirement program. Retirement income programs are intended to provide not only tangible cash benefits upon retirement, but also the intangible benefit of security during a future beneficiary's working years. If the promise of benefits is unfulfilled, retirees and those close to retirement age are injured at a time in their lives when they are least able to adjust. Retirement income generally accrues over one's entire work life. A person cannot easily replace it a few years before it is needed. Some people may be able to continue working but many may not, either because of poor health or loss of employment. The only choices available may be to rely on means-tested welfare or to move in with relatives. Either circumstance subjects the individual to a devastating loss of independence. Because of this acute vulnerability, people must be able to rely on the long-term promises of retirement income programs if these programs are to accomplish the intended goal of providing security during the working years.

A promise of retirement income made today but not payable for more than forty years, however, is inherently insecure. This is true whether a private actor or the government makes the promise, although the nature of the insecurities differ. A private promise may fail because the promisor may no longer be in existence. Alternatively, the promisor may have insufficient funds to pay the obligation. If the funds are set aside in advance, the obligation may still be unsatisfied as a consequence of poor investment management or a misappropriation of the

25 For an interesting discussion of three alternative conceptual models of Social Security-the tax-transfer model, the insurance model, and the annuity-welfare model-and the different policy directions in which they lead, see Thompson, The Social Security Reform Debate, 21 J. EcoN. LITERATURE 1425, 1436-38 (1983).

${ }_{26}$ Professor Graetz, as well as others, have found fault with the tax in part because it is assessed on first dollars earned, without any exemptions or deductions to reflect differing expenses of taxpayers. See Graetz, supra note 2, at 864-65; see also Pechman, supra note 22, at 182 . Some have defended the tax by pointing to the progressive benefit formula. See, e.g., R. MYERS, supra note 3, at 455 ("Critics of the payroll taxes . . . are quick to point out that they are regressive. . . . But when both sides of the coin are considered-benefits and taxes-OASDI and HI are definitely not regressive. Looking merely at the tax side is playing ostrich."). Professor Graetz dismisses this argument on a number of grounds. See Graetz, supra note 2, at 872-74 (arguing that the retirement income system as a whole has a far less redistributive effect than Social Security alone, and that Social Security does not come close to replacing the full income of low earners). 
set-aside funds. In contrast, the permanence of the national government and its ability to levy taxes eliminates the insecurities of the private promise. No Congress, however, can bind itself or its successors to maintain statutory entitlements. As a consequence, a commitment of future benefits made by the government is politically insecure.

For a public system of retirement income to accomplish its goals, this inherent political insecurity must be addressed. If people are unable to depend on the long-term continuation of Social Security, the program ceases to function as intended; it provides retirement income only, not retirement security. People, of course, depend on all government spending programs to some extent. However, people depend on Social Security in a manner different from their reliance on most other government programs, because they plan for retirement many years in advance, because retirement programs generally provide income for basic support, and because older people often lack the flexibility to adjust to losses of income. ${ }^{27}$ As a consequence, the government has an obligation to attempt to ensure the long-term continuation of Social Security.

The original architects of the Social Security program ingeniously responded to the need for long-run security by creating a self-financing program through the use of an earmarked payroll tax, the proceeds of which were to be held in trust funds segregated from the government's general operating fund. ${ }^{28}$ These features set Social Security apart from other government programs. Although Congress has the power to reduce or eliminate Social Security benefits ${ }^{29}$ and has on occasion done so, ${ }^{30}$ the retention of the program's financial structure has reinforced

27 People's reliance on discretionary grants is clearly different, since no particular applicant for a grant can be assured of receiving it. Although the distinctions are not as striking when Social Security is compared to other entitlements, differences do exist. For example, people may depend on guaranteed student loans. If the program were repealed, however, individuals could still receive an education. They could enroll in less expensive colleges, work part-time, or defer their educations for a few years while they worked and saved. In contrast, if Social Security were repealed, many people could not ever retire. See President's Commission on Pension Policy, Coming of Age: ToWard a National Retirement Income Policy 166 (1981) [hereinafter PresiDent's Commission on PENSION Policy].

${ }^{28}$ See Social Security Act, Pub. L. No. 74-271, 49 Stat. 620 (1935) (codified as amended at 42 U.S.C. $§ 401-33$ (1982 \& Supp. III 1985 \& West Supp. 1987)). Over the course of Social Security's history, there have been transfers of general revenue, but generally only to finance the benefits of special, small closed groups in certain limited situations. See, e.g., 42 U.S.C. § 428(g) (1982 \& Supp. III 1985) (providing appropriations for reimbursement of the Social Security trust funds with respect to benefits paid to people otherwise uninsured who attained age 72 before 1968).

${ }_{28}$ The promise of Social Security benefits is not a binding contractual right. See, e.g., Flemming v. Nestor, 363 U.S. 603, 608-11 (1960) (upholding the termination of the Social Security benefits of an alien deported for having been a member of the Communist party).

30 Benefits were curtailed as early as 1939 and as recently as 1983. See Social 
the perception that Social Security is different from other federal programs. Moreover, policymakers have bolstered and protected the perceived special status of Social Security in other ways. For example, in 1983, at the same time that Congress reduced Social Security benefits, it removed the program from the unified budget. ${ }^{31}$ Removing Social Security from the unified budget is largely a symbolic change. Nevertheless, it sets the program apart and underscores the policymakers' determination to keep the program secure for future retirees.

\section{A. The Conceptual Basis of Social Security}

Some analysts believe that the earmarked tax, its designation as a "contribution" rather than a tax, and other attributes designed to signal Social Security's special status, are cynical and undemocratic attempts by its supporters to conceal the program's "true" nature. ${ }^{32}$ It is not these relatively superficial features, however, that cause Social Security to be politically stable. Rather, these features illuminate and dramatize the program's underlying conceptual core. Social Security is popular and, therefore, secure, because it is social insurance, not welfare. Professor Graetz's proposals would inadvertently weaken the long-run stability of Social Security by transforming it from a social insurance program to a welfare program.

The distinction between social insurance and welfare is significant. The concepts are derived from separate historical traditions and have

Security Act Amendments of 1939, Pub. L. No. 76-379, 53 Stat. 1360 (codified as amended at 42 U.S.C. $\S 402$ (1982 \& Supp. III 1985)) (eliminating a lump-sum payment at death that approximated the excess, if any, of employee contributions paid, plus an allowance for interest, over benefits received); Social Security Amendments of 1983, Pub. L. No. 98-21, 97 Stat. 65 (codified as amended at 42 U.S.C. $§ 415$ (Supp. III 1985 \& West Supp. 1987); 42 U.S.C. \& 416 (Supp. III 1985)) (delaying the cost of living adjustment for six months and gradually raising the age from 65 to 67 at which full benefits are paid).

31 Removing Social Security from the unified budget simply requires that its expenditures and revenues be reflected separately from the rest of the federal budget and not be included in the overall budget balance. The removal was to be effective starting in 1992. See Social Security Amendments of 1983, Pùb. L. No. 98-21, 97 Stat. 65 (codified at 42 U.S.C. § 911(a) (Supp. III 1985)). However, in 1985, Congress made the removal effective in 1986 but included the program in budget calculations for purposes of meeting the Gramm-Rudman-Hollings targets. See Balanced Budget and Emergency Deficit Control Act of 1985, Pub. L. No. 99-177, tit. 2, 99 Stat. 1038 (codified at 42 U.S.C. $§ 911$ (Supp. III 1985)). For a discussion of the history and issues concerning the interrelationship of Social Security and the unified budget, see $\mathbf{R}$. MYERS, supra note 3, at 370-72.

32 See, e.g., M. Derthick, Policymaking for Social Security 224-27 (1979) (reporting comments of critics in the 1930s, 1940s and 1950s); see also P. FerRara, Social Security: The Inherent Contradiction 16 (1980) ("[F]alse impressions and beliefs have been created by the ... blatant misrepresentations of social security by politicians and government officials over the years."). 
resulted in programs containing sharply divergent features. ${ }^{33}$ During the Middle Ages, workers in guilds contributed portions of their wages to protect themselves and their families in the event of lost earnings due to death or disability. These and subsequent contributory worker programs developed as a consequence of insecurities against which workers could not individually protect themselves. The programs involved the concerted activities of the entire community. Government programs of social insurance evolved from these self-help worker programs. ${ }^{34}$ Consistent with its origins, Social Security requires that all workers contribute some wage-related amount for their benefits and that the longer workers are employed and the higher their covered earnings, ${ }^{35}$ the greater their cash benefits. ${ }^{36}$ Because benefits are tied to previous living standards, Social Security encourages work. ${ }^{37}$ Assets are irrelevant to benefit determinations, so savings are encouraged. Finally, because retirees need only show that they have worked the requisite number of quarters to qualify for benefits, ${ }^{38}$ Social Security maintains the dignity of recipients.

In contrast to social insurance, welfare is grounded exclusively in the concept of need. Its historical roots lie in private charitable efforts, which later developed into government programs of assistance to the poor. ${ }^{38}$ These programs have frequently contained oppressive and punitive features. ${ }^{40}$ Consistent with this historical tradition, eligibility for

${ }^{33}$ For a similar discussion of the distinctions, see $\mathrm{R}$. Ball, The Original Understanding of Social Security: Implications for the Future 2-4 (paper delivered at the Yale Social Security-Medicare Symposium) (on file with the University of Pennsylvania Law Review) (forthcoming in SocIal SECURITY: BEYOND THE RHETORIC OF GRISIS (T. Marmor, J. Mashaw, eds. 1988)). See also Munnell, The Current Status of Our Social Welfare System, NEw ENG. ECON. REv., July-Aug. 1987, at 3, 5-8 (describing the history and differences between social insurance and welfare and comparing the provisions of Social Security, SSI, and Aid to Families with Dependent Children).

${ }^{34}$ See Ball, supra note 33, at 2.

35 For a definition of covered wages or earnings, see supra note 22 . Because the five lowest years of earnings are disregarded in calculating benefits, two workers could have different earnings in those five years and nevertheless have identical benefits.

${ }^{36}$ The Hospital Insurance portion of Social Security (i.e., Part A of Medicare) is available to, among others, all people over age 65 who are eligible for the cash benefits under Social Security. See 42 U.S.C. § 426(a) (1982 \& Supp. III 1985 \& West Supp. 1987). Despite higher contributions by some, all beneficiaries are entitled to the same benefit package.

${ }_{37}$ See 42 U.S.C. $\S 415($ a)-(b) (1982 \& Supp. III 1985 \& West Supp. 1987) (the primary insurance amount is based upon the worker's average indexed monthly earnings).

${ }^{38}$ See 42 U.S.C. $\S 414$ (1982 \& Supp. III 1985) (requiring a showing of number of quarters of coverage to qualify for benefits).

so See F. Piven \& R. Cloward, Regulating the Poor: The Functions of Public Welfare 9-11 (1971).

40 See id. at 32-38 (discussing the degradation of those on relief). 
the nation's welfare programs is conditioned on satisfying strict means tests that measure current income and asset levels of potential recipients. Benefits bear no relationship to previous standards of living; rather, benefits are designed merely to satisfy a standardized, community-determined, minimal level of need. Neither eligibility nor benefit amounts are in any way contingent on prior taxes paid or prior earnings. Because welfare programs provide flat grants and because earnings are offset in whole or in part from payments, ${ }^{41}$ welfare discourages work. Moreover, because welfare is based on need, families cannot qualify unless they have virtually no assets. The result is that welfare discourages saving. Finally, welfare is inherently demeaning because applicants must demonstrate that they are incapable of providing for themselves.

Two basic principles of program design, then, are fundamental to the difference between Social Security and welfare. First, Social Security eligibility depends on wage-related contributions. Welfare eligibility, in contrast, is based exclusively on need. Second, Social Security benefit levels vary with earnings and length of work. Higher past earnings and more years of work result in higher cash benefits. These factors are irrelevant to the determination of welfare benefits. Rather, the level of welfare benefits depends on need. Higher current earnings result in lower benefit amounts.

Some analysts blur the distinction between social insurance and welfare by characterizing the redistributive features of Social Security as welfare. ${ }^{42}$ Redistribution alone, however, does not determine whether a benefit is insurance or welfare. All insurance is in some sense redistributive. If, for example, one purchases health insurance, and the next day becomes seriously ill, the insured receives benefits of much greater value than the amount of the premium paid. Those insured individuals who remain healthy and receive no benefits have, in effect, redistributed their premium amounts to the now ill beneficiary.

Some argue that the analogy between the redistributive features of

41 See, e.g., 42 U.S.C. $§$ 602(a)(7) (1982 \& Supp. III 1985 \& West Supp. 1987) (requiring that states participating in the Aid to Families with Dependent Children program develop a standard of need that takes into account certain earnings and asset levels of potential recipients).

12 See, e.g., C. Weaver, The Crisis in Social Security: Economic and PoLITICAL ORIGINS 187-89 (1982) (arguing that the redistributive effects of intergenerational and intragenerational transfers are unfair); Parsons \& Munro, Intergenerational Transfers in Social Security, in The Crisis in Social Security: Problems and Prospects 65, 66 (M. Boskin ed. 1978) (describing the so-called welfare components of Social Security). See generally Thompson, supra note 25, at 1437-38 (describing the view of those who conceptualize Social Security as partially insurance and partially welfare). 
Social Security and private insurance is misleading. Those who make this claim assert that the benefits must be viewed prospectively. When so viewed, private insurance benefits are actuarially related to premiums. ${ }^{43}$ This quality, however, describes Social Security, as well. From an individual participant's perspective, Social Security, like private insurance, is only redistributive when examined ex post facto. When workers join the work force, they do not know, for example, whether they will suffer disability, unemployment, or premature death. They cannot foresee whether they will have dependents at the time of an insurable event. Depending on these and other circumstances, particular individuals may receive benefits that are larger or smaller than contributions paid.

Social Security benefits and contributions, moreover, are actuarially based. The Social Security Administration employs a large staff of actuaries who produce annual reports detailing the actuarial status of the various funds. ${ }^{44}$ Although benefit levels include intragenerational and intergenerational subsidies, and therefore benefits and contributions are not actuarially equivalent, many private insurance plans lack equivalence as well. Indeed, most private group health insurance and defined benefit pension plans contain a variety of cross-subsidizations. ${ }^{45}$ Social insurance is labeled "social" because, unlike private insurance, it insures against certain social conditions, such as low wage levels and large numbers of dependents. Protection against these risks, however, does not transform what is otherwise insurance into welfare.

One feature of Social Security that seems especially welfare-like is that beneficiaries with lower average covered earnings receive a greater benefit as a proportion of those earnings than beneficiaries with higher average covered earnings. ${ }^{48}$ Although this aspect of the program causes

43 See, e.g., Simon, Rights and Redistribution in the Welfare System, 38 STAN. L. Rev. 1431, 1445 (1986) ("Insurers] insist that the proper way to look at [insurance] is prospectively-at the time terms are agreed to and the actual pattern of losses is known only probabilistically. . . . In the paradigmatic, or 'actuarially fair,' insurance contract, there is no redistribution because the present value of each insured's premium payments equals the present value of the insurer's liability.").

4 See supra note 18.

45 For example, the use of gender-specific mortality tables in calculating retirement benefits under employer-sponsored pension plans has been held to be unlawful. See Arizona Governing Comm. v. Norris, 463 U.S. 1073, 1077 (1983) As a consequence of the shorter life expectancies of men, unisex mortality tables cause men to subsidize women in the provision of life annuities and women to subsidize men in the provision of survivor benefits.

${ }_{46}$ Those with low average covered earnings will tend to be low-income workers. In addition to low-income workers, though, intermittent workers and workers who have worked most of their careers in noncovered service also receive proportionately higher benefits because the Social Security benefit formula uses indexed earnings averaged over a specified number of years (ultimately 35 ), and years without covered earnings 
redistribution from higher-income workers to lower-income workers, it is, nevertheless, reconcilable with insurance principles. ${ }^{47}$ Indeed, the feature is in striking contrast to the attributes of welfare described above.

Although lower-income workers receive higher proportionate benefits under Social Security, the benefit structure ensures that those with higher covered earnings receive higher dollar amounts in absolute terms. This outcome is the consequence of a progressive benefit formula, similar in concept to the progressive rates of the federal income tax system. ${ }^{48}$ The formula divides earnings into three brackets. As in the income tax system, each bracket has a percentage rate associated with it. The first dollars of earnings are replaced at the highest percentage rate, the next level of bracketed earnings at a lower rate, and the highest earnings at the lowest rate. Workers with the very lowest levels of earnings have all their earnings contained within the first bracket and consequently replaced at the highest percentage rate.

The disproportionately large benefits received by low-income workers are properly perceived not as welfare, but as basic benefits that every beneficiary receives. The Social Security benefit of every beneficiary consists of a portion that is based on those earnings that are

are included in the average as zero years. See 42 U.S.C. $\S 415$ (1982 \& Supp. III 1985 \& West Supp. 1987).

47 Another feature of Social Security that involves substantial redistribution is the benefit provided to dependent spouses. This aspect of the program has been criticized in recent years for its apparent unfairness to working women. As a consequence of the availability of a generous benefit for dependent spouses of workers, families consisting of workers with spouses employed at low wages may receive no higher cash benefits than families with one wage worker and a nonwage-earning spouse. (It should be noted that the wage-earning spouse does receive disability and survivor benefit protection, which the nonwage-earning spouse does not.) See Congressional Budget OfFice, Earnings Sharing Options for the Social Security System 12-13 (1986). The spousal benefit arguably is controversial because it violates one of the two core principles outlined in the text. Wage-earning spouses who receive only the amount of the dependent spouse's benefit, but no additional benefit based on their own earnings, fail to receive more as a result of their work efforts. Nevertheless, this provision is actually consistent with the basic principles of Social Security. The criticisms should instead be viewed as a product of the change in the status of women in the last 50 years. In the 1930s, wives arguably were not seen as separate from their husbands. Moreover, women did not enjoy legal protection against gender discrimination in employment. In such a society, it made sense for male workers to insure against the risk of a dependent spouse. Today, however, many women work and are insured in their own right under Social Security. The program has not adjusted to the current status of working women, and instead provides those women (and those men who earn less than half of what their wives earn) with overlapping protection, both as workers and as dependent spouses. This is an aspect of the program that should be corrected.

${ }^{48}$ For a detailed description of the way in which benefits are calculated, see $R$. MYERS, supra note 3, at 49-89, 147-68. See also Altman, supra note 8, at 476-78 (discussing the progressive nature of Social Security). 
within the first bracket of the formula. Higher-income workers receive lower rates of return because their benefits are based in part on earnings that fall within the remaining two brackets. These workers, in effect, contribute towards and are entitled to supplemental benefits-those additional dollars that result in a larger benefit in absolute terms.

Neither private insurance nor any of the nation's means-tested welfare programs contains the kind of benefit formula found in Social Security. Rather, the formula is an appropriate feature of social insurance. No workers-not even highly-trained professionals-know at the beginning of their working years whether they will have low career earnings. Low career averages can result not only from low-wage jobs, but also from a variety of uncontrollable occurrences such as illnesses, disabling accidents, premature death, or periods of unemployment. Consequently, Social Security properly protects all workers against those eventualities.

\section{B. A Critique of Professor Graetz's Proposals in Light of Social Security's Conceptual Core}

This nation would certainly be more humane if it accorded equal value to programs developed around the contrasting principles of social insurance and welfare. The nation, however, seems to prefer the values of work, self-help, and saving, embodied in the tradition of social insurance, to the values of charity and compassion embodied in welfare. ${ }^{49}$ As a result, proposals to change Social Security should be evaluated in terms of their effect on the program's social insurance values. These values keep Social Security politically popular and, consequently, give it the stability essential for current workers to be able to rely on its continuation.

In the name of tax justice, Professor Graetz's proposals would inadvertently introduce elements of welfare into the design of Social Security. Professor Graetz proposes that low-income workers be exempted

18 Professor William Simon describes a choice that was available in the 1930 s to structure Social Security around the concept of need, rather than around the private law concepts of contract and insurance. Professor Simon acknowledges that the choice was resolved by President Roosevelt on political grounds, but he seems to believe that the choice to condition Social Security on need could have resulted in a Social Security program as politically stable as the current one. See Simon, supra note 43, at 1431-33, 1448-54. Of course, no one can know today what the effect would have been if a different choice had been made. Nevertheless, today, programs developed around the concept of insurance are more politically stable than programs developed exclusively around the concept of need; the former are less likely to be reduced in times of fiscal constraints. See id. at 1465-66. 
from the Social Security payroll tax. ${ }^{50}$ These workers presumably would be eligible for some minimum benefit amount even though, as a consequence of the exemption, they would pay no payroll tax. ${ }^{\mathbf{5 1}}$ As an alternative, Professor Graetz would have these workers pay taxes for some minimal number of quarters in order to qualify for bênefits. ${ }^{52}$ Both proposals sever the important connection between length of work and amount of earnings on the one hand, and level of benefits on the other hand. ${ }^{53}$

If a complete exemption from the payroll tax became law, lowincome workers would be perceived as getting Social Security benefits for free. In that case, it would be difficult to justify differentiating between those receiving the lowest Social Security benefit and those qualifying only for means-tested SSI benefits. Workers covered under Social Security would have a slightly greater attachment to the work force, but if they were making no contributions to Social Security, this greater connection to the work force would hardly seem to justify their qualification for a separate and more generous income support program. ${ }^{54}$ If the two programs were combined, as would then seem warranted, asset tests and other restrictions might be introduced to promote equitable treatment among recipients and to prevent abuses, such as the receipt of the low-income benefit by undeserving wealthier individuals who did not otherwise qualify for Social Security. Whether or not the programs were combined or restrictive tests were added, people would generally

so See Graetz, supra note 2, at 864-68 (arguing that the payroll tax is an unfair burden on low-income workers).

s1 See id. at 906-07. Although Professor Graetz does not make clear whether he would alter the benefit formula of Social Security in conjunction with the introduction of an exemption for low-income workers, he presumably would introduce a minimum benefit for all workers falling within the exempt amount. Otherwise, some would receive larger benefits simply because of higher wage levels, even though they would not have contributed more dollars to the program.

${ }^{52}$ See id. at 864-68.

${ }^{53}$ In addition to the conceptual shortcomings, significant technical problems with these proposals exist. For example, an exempt amount would require reconciliation for workers who were employed part-time for several employers or who changed jobs in the middle of the year. In addition, some employees would pay no taxes some years, and some taxes other years. A benefit formula that was fair to these workers would have to be developed. With respect to disability insurance, part of the vesting requirement demands recent attachment to the work force. See 42 U.S.C. $\S 423$ (c)(1) (1982 \& Supp. III 1985). As a consequence, unless this provision were eliminated, these workers would lose their disability protection shortly after ceasing to contribute.

54 Under current law, individuals over age 65 who have not had a substantial attachment to the work force may qualify for SSI in place of or in addition to Social Security. See 42 U.S.C. § 1381 (1982 \& Supp. III 1985); 42 U.S.C. § 1383(c) (1982 \& Supp. III 1985 \& West Supp. 1987). Social Security currently employs no asset tests. Moreover, depending on the level of the minimum benefit, Social Security might also provide higher benefits. 
recognize that for those receiving the lowest benefit, the earned-right quality of the program had disappeared.

Similar problems exist under Professor Graetz's alternative proposal requiring a minimal payment from low-income workers. This alternative proposal satisfies one core principle of Social Security-that a worker must contribute in order to qualify for benefits-but it violates the principle that one's benefits will be higher with more years of work. The current benefit structure provides larger benefits in absolute terms not only for workers with higher earnings, but also for workers with more years of coverage. ${ }^{55}$ Professor Graetz's proposal would limit all low-income workers to a predetermined minimum, despite the greater work effort of some. Again the linkage to work, a fundamental value underlying Social Security, would be lost. ${ }^{56}$

Professor Graetz's proposal to subject earnings above the taxable wage base to the payroll tax, while holding the level of benefits constant, suffers from the same kinds of problems as his proposal to exempt low-income workers. As described above, benefits currently are based on the earnings on which the payroll tax is assessed. In that way, those who have higher covered earnings receive higher benefits in absolute terms. If workers with higher covered earnings were receiving the same benefit amounts as workers with lower earnings, the important connection between earnings and benefits again would be severed. ${ }^{57}$

BS The Social Security benefit formula is based on workers' average indexed monthly earnings over their careers. The number of years used is the number of years between 1950 or attainment of age 21, whichever is later, and attainment of age 62, minus five years. Because wages are indexed to the growth of wages in the overall economy, and because the highest earning years are used in computing the average, the longer one works, generally, the higher one's monthly average and corresponding benefit will be. See 42 U.S.C. § 415 (1982 \& Supp. III 1985 \& West Supp. 1987).

so Congress included a minimum benefit in the 1935 statute primarily for administrative reasons. In 1977, Congress froze the initial amount and in 1981, eliminated the benefit for almost all those first becoming eligible after 1981. A special minimum benefit is available for those with very low earnings but a substantial number of years of covered employment. See 42 U.S.C. $\S 415(\mathrm{a})(1)(\mathrm{C})(\mathrm{i})$ (1982 \& Supp. III 1985 \& West Supp. 1987). For a discussion of both of these benefits, see R. MYERS, supra note 3 , at 78-84.

${ }^{87}$ Proposals have been made to eliminate the taxable wage base without changing the benefit formula. In that case, those individuals with earnings in excess of the current base would receive higher benefits. These proposals, however, have been controversial in part because, due to the higher benefits, they would not result in substantial long-term savings. See Staff of Senate Comm. on Finance, 97th Cong., 1st Sess., Staff Data and Materials Related to Social Security Financing 45 (Comm. Print 1981) ("large benefit levels and long-range benefit costs . . . substantially offset the additional revenue"). 


\section{Alternative Solutions to Professor Graetz's Concerns}

Retaining the two fundamental design features of Social Security identified above is important to the stability of the program. At the same time, concerns about the retirement income system should not override other equally important policy goals, including those articulated by Professor Graetz. His tax equity concerns, however, can be satisfied in a manner more consistent with the requirements of the Social Security program.

Professor Graetz is properly concerned about the burden that the payroll tax imposes on the working poor. Partly in response to this burden, Congress in 1975 enacted the Earned Income Tax Credit ("EITC"). ${ }^{58}$ The EITC gives eligible low-income workers a tax credit to be applied against their income taxes. The credit is refundable so that workers with no tax liability can nevertheless receive its benefit. Professor Graetz mentions the EITC in passing, but dismisses it as inferior to his proposed solution of exempting low-income workers from the coverage of the payroll tax. ${ }^{50}$ If the appropriate policy concern to be addressed is the unfairness of the payroll tax, Professor Graetz's conclusion is correct, but tautological. His focus on the payroll tax alone, however, is too narrow.

Just as all our retirement programs should be evaluated as one comprehensive system, so too the overall burdens on the working poor should be addressed comprehensively, not piecemeal. In addition to the payroll tax, the working poor have at times been burdened by the income tax. ${ }^{60}$ To the extent that employer taxes are borne by workers, ${ }^{61}$ employer payments for unemployment compensation and for workers' compensation further burden low-income workers. The cumulative tax burden on the working poor is inconsistent with notions of ability to pay. Moreover, work expenses create an additional hardship for lowincome employees. The taxes and work expenses create significant work disincentives for the poor. These costs of working inadvertently

s8 See Tax Reduction Act of 1975, Pub. L. No. 94-12, § 43, 89 Stat. 26, 30 (codified as amended at I.R.C. $\S 32$ (1982 \& Supp. III 1985 \& West Supp. 1987)). Since this enactment, Congress has increased the size of the credit and the income level at which it phases out, partly in response to increases in the Social Security payroll tax. See Joint Commission on Taxation, General Explanation of the Tax ReFORM ACT OF 1986, at 27 (1987).

58 See Graetz, supra note 2, at 866 (calling the EITC "an inadequate substitute for a minimum income level for exemption from the social security tax burden").

Bo Six million low-income families who had been subject to the federal income tax were removed from the rolls by the Tax Reform Act of 1986. See id. at 865 .

61 See id. at 867 ("Economists generally agree that both the employers' and the employees' shares of social security taxes are borne by employees in the form of reduced wages."). 
increase the comparative attractiveness of welfare. More fundamentally, the costs undercut the good-faith effort of those who are struggling to escape poverty.

When the policy goal is more appropriately defined either as encouraging the work effort of the poor, or, more narrowly, as alleviating the tax burden of the poor, the strength of the EITC and the weakness of an exemption from the payroll tax becomes clear. ${ }^{62} \mathrm{~A}$ payroll tax exemption, by definition, is limited to the amount of the payroll tax. In contrast, the EITC can be increased to take into account other taxes and expenses of the working poor. The EITC historically has been larger for low-income workers than the cost of the employee FICA contribution. ${ }^{63}$ Moreover, the EITC is fairer to family units. Under a payroll tax exemption, two-earner families would receive double exemptions even though the family income might be the same as a singleearner family. The EITC provides the identical relief to each taxpaying unit with identical income.

Furthermore, a large number of low-income workers are members of families which are not poor. ${ }^{64}$ The payroll tax exemption would give these families unwarranted benefits. In contrast, the EITC better targets benefits to low-income workers who are part of poor families. ${ }^{65}$ Moreover, the degree to which taxes and work expenses are burdensome depends upon the number of people supported by a worker's wages. Although the EITC currently does not take family size into account, it could be so modified. ${ }^{68}$ This modification would be adminis-

62 In addition to an exemption from the payroll tax or a tax credit, the government could alleviate some of the burden on the working poor through a variety of other methods including wage supplements, a guaranteed minimum income, a negative income tax, or an increase in the minimum wage. For a discussion of the advantages and disadvantages of a negative income tax and a wage subsidy program, see M. BARTH, G. Carcagno \& J. Palmer, Toward an Effective Income Support System: Problems, Prospects and Choices 52-58, $72-78$ (1974). For a discussion of the advantages and disadvantages of increasing the minimum wage, see Reischauer, Welfare Reform and the Working Poor, in WORK AND Welfare: The Case for New Directions in National Policy 35, 41-42 (1987).

${ }_{63}$ The level of the EITC has tended to be at about the level of the combined employer-employee tax rate. For example, the EITC is currently $14 \%$ of the first $\$ 5,714$ (adjusted for inflation) of an eligible person's earned income. The credit phases out between the income levels of $\$ 9,000$ and $\$ 17,000$. See I.R.G. $\S 32$ (1982 \& Supp. III 1985 \& West Supp. 1987). The FICA rate for 1988 is $7.51 \%$ on employees and employers each for a combined rate of $15.02 \%$. See I.R.C. $\$ \S 3101$ (a)-(b), 3111(a)-(b) (1982 \& Supp. III 1985 \& West Supp. 1987).

64 See M. Barth, G. Garcagno \& J. Palmer, supra note 62, at 73.

${ }^{\text {Bs }}$ The EITC has targeting problems of its own. Because the credit is refundable, those with little or no tax liability as a result of tax-sheltered income receive a windfall. See Graetz, supra note 2, at 866 n.52 (quoting Steuerle \& Wilson, The Taxation of Poor and Lower-Income Workers, 34 TAX NOTES 695, 702-03 (1987)).

Be This modification has been forcefully advocated and may yet become law. See, 
tratively simpler than including a comparable feature in the proposed payroll tax exemption. Finally, the EITG also provides a more refined work incentive. It phases out as income increases. Consequently, the marginal rates facing low-income workers are moderated. An exemption from the payroll tax would impose a much higher marginal rate on the first dollar earned above the exempt amount.

As Professor Graetz notes, the EITC has weaknesses. ${ }^{67}$ Currently, only families with children can claim it. Further, Professor Graetz speculates that the credit is probably not claimed by all those eligible to receive it. ${ }^{68}$ These defects are serious but correctable, at least in part. Eligibility for the credit should be expanded to include single workers and childless couples in order to benefit all low-income workers. Measures should be taken to ensure its usage by those eligible to claim it. ${ }^{69}$ If these changes are made, the EITG will be even more effective in assisting the working poor and will do so without undermining Social Security, a program that has protected millions of people from an impoverished old age. ${ }^{70}$

Professor Graetz's concern about the regressivity of the payroll tax with respect to the highest-income taxpayers is also important. ${ }^{71}$ Here again, though, the problem should be addressed comprehensively without undercutting the political acceptability of Social Security. If the issue is whether federal taxes are progressive when viewed in a unitary manner, the federal tax burden should be analyzed comprehensively, as Professor Graetz seeks to do. When viewed this way, it becomes clear that a number of alternatives are available to satisfy Professor Graetz's concerns.

e.g., Reischauer, supra note 62 , at 42 .

${ }^{67}$ See Graetz, supra note 2, at 866-67.

${ }^{68}$ See id. Under current law, employers are required to take the credit into account for withholding purposes; they must be presented, however, with a certificate by the eligible employee. Moreover, if the credit owed employees is greater than the amounts of taxes required to be withheld and paid the government, the employer may either pay only a portion of the credit owed employees or treat the excess payments as advance tax payments. If the employer does not pay the full amount of the credit through the reverse withholding mechanism, employees who otherwise might not have to file income tax returns would have to file in order to receive the full amount of the credit. See I.R.C. § 3507 (1982 \& Supp. III 1985 \& West Supp. 1987).

${ }^{89}$ Congress should provide the Internal Revenue Service with increased resources to discover those eligible for the credit and to assist them in obtaining the necessary certificate. In addition, those employers who have credits in excess of withholding should be required to pay the credit, but at the same time be permitted to claim an immediate refund that should be provided on an expedited basis. Congress might consider providing some form of special relief for any administrative costs incurred, especially by small employers, in providing the credit.

${ }_{70}$ See President's Commission on Pension Policy, supra note 27, at 166.

${ }^{71}$ See Graetz, supra note 2, at 864-65, 868-69. 
Although altering the incidence of the payroll tax is one approach, a different solution, contained in the Internal Revenue Code, is at least partly in place. In 1983, Congress provided that up to one-half of the Social Security benefits of high-income taxpayers would be included in their taxable incomes. ${ }^{\text {22 }}$ Although subjecting Social Security benefits to the federal income tax does not respond to Professor Graetz's concern directly, it does so indirectly. Professor Graetz would require the highest-income workers to pay more taxes in order to qualify for the same level of benefits as those who pay lower amounts. ${ }^{73}$ Under an appropriately progressive income tax system, the inclusion of Social Security benefits in taxable income would result in higher-income workers making the same levels of contributions as lower-income workers, but receiving lower benefits when viewed on an after-tax basis.

For the taxation of Social Security benefits to satisfactorily address the equity concerns of Professor Graetz, the federal income tax system would have to be made more progressive in light of the lack of progressivity of the payroll tax and other federal taxes. ${ }^{74}$ Rather than altering the payroll tax, perceived inequities in the overall federal tax burden should be corrected through the federal income tax system. It is the nation's largest federal revenue source. Its central mission is the raising of revenue. As a result of its size and mission, it is well equipped to temper distributional problems in the payroll tax. Making the federal income tax more progressive, in addition to subjecting at least a portion of the Social Securiiy benefits to that tax, substantially solves Professor Graetz's tax justice concerns. Significantly, it does so while leaving intact the fundamental structure of Social Security so important to its

${ }^{72}$ See I.R.C. $\S 86$ (Supp. III 1985). In order to parallel the treatment of the taxation of private pensions and avoid double taxation, a maximum of one-half the benefit is taxed. The one-half is deemed to represent the employer's portion on which a deduction is claimed at the time of contribution. The employer and employee contributions with imputed interest historically, however, have not represented more than $20 \%$ of the benefit received. Therefore, it might be appropriate to tax the full benefit, after the amount paid has exceeded taxes paid by the worker, which should result in a greater portion of the benefit being taxed. See Ball, Insuring Our Future: The Financing of Social Security and Medicare, NAT'L Voter, March-April 1986, at 6, 13. Professor Graetz mentions the 1983 amendment, but does not discuss it in the context of the maximum taxable wage-base. See Graetz, supra note 2, at 860.

${ }^{73}$ See Graetz, supra note 2, at 870-72.

${ }^{74}$ Unfortunately, the motivation behind the Tax Reform Act of 1986 was to simplify the rate structure rather than to increase the overall progressivity of the tax system. See J. Birnbaum \& A. Murray, Showdown at Gucci Gulch 288-89 (1987) (The authors document the political struggles that gave birth to the 1986 Tax Act: " $[R]$ eform narrowed the enormous inequities that permeated the existing tax system. Although it made no fundamental changes in the distribution of the tax burden among income groups, it did make it more likely that individuals and corporations with similar incomes would pay similar taxes. In that way, it made the tax system more fair."). 
long-term acceptability.

\section{In Defense of Voluntary Employer-Provided Pensions and the Concomttant TaX Subsidy}

In addition to criticizing the Social Security payroll tax, Professor Graetz finds fault with the other major tax element of our retirement income system, the tax expenditure for employer-sponsored pensions. He points out that both the private pensions themselves and the tax savings associated with them disproportionately benefit high-income workers. ${ }^{75}$ Professor Graetz hints that his preferred retirement income system would include mandatory employer-sponsored pension plans, but he dismisses the idea as politically unrealistic. Instead, he proposes imposing either a flat income tax on the investment earnings of pension funds or, alternatively, an excise tax on the total assets of these funds. ${ }^{76}$ He would then use the proceeds to raise Social Security benefit levels for low- and moderate-income workers and to modify the payroll tax. ${ }^{77}$ While Professor Graetz's criticisms are sound, his conclusion, that the role of voluntary private pensions should be diminished or eliminated, is unwarranted. Moreover, his narrow focus on tax equity causes him to ignore the adverse effects his proposal might have on the stability of Social Security.

Professor Graetz correctly notes that the reliance on voluntary private pensions as part of our national retirement income system is problematic. ${ }^{78}$ First, not all employers will establish plans, even in the face of favorable tax treatment. ${ }^{78}$ Second, the reliance on voluntary plans requires, but is in tension with, extensive and complicated regulations. While some of the reasons employers establish private pensions are consistent with a national retirement policy, some are different from or may even be inconsistent with broader policy. For example, in the ab-

${ }^{75}$ See Graetz, supra note 2, at 874-94, 906-08. "The revenue loss attributable to private pensions has been estimated to benefit high-income workers disproportionately, and the distribution of benefits from private pension plans is skewed in the same direction." Id. at 876.

${ }^{76}$ Id. at 908 . Trust funds that are part of tax-qualified employer-sponsored pension, stock bonus, and profit-sharing plans are tax exempt. See I.R.C. $\S \S 401$ (a), 501 (a) (1982 \& Supp. III 1985 \& West Supp. 1987).

77 See Graetz, supra note 2 at 871-72.

${ }^{28}$ See id. at 878 ("To use conditional tax incentives as a principal mechanism for regulation poses an immediate dilemma because of the voluntary nature of employerprovided pension plans. On the one hand, the creation of pension regulations always reflects a concern that making qualification too difficult will inhibit the establishment of pension plans. On the other hand, there is little public gain in subsidizing employee plans that provide minimal or no benefits to low- and moderate-income workers.")

79 See E. ANDREWS, supra note 4, at 12-16. 
sence of regulations, employers are likely to be concerned primarily with structuring their plans to discourage resignations by those employees whom they perceive to be indispensable and to reward those whom they perceive to be loyal. Moreover, younger workers may not appreciate the value of retirement savings, and employers will be indifferent to their coverage. ${ }^{80}$ In contrast, the government must be concerned about the retirement security of every person, including those who change jobs frequently; those who leave to work for competitors; intermittent workers; young workers; and nonwage-earning spouses. To the extent the government and employer interests are in conflict, the government must seek to channel the employer's actions toward broader social purposes. ${ }^{81}$ Today, there are participation rules, coverage rules, vesting rules, and a variety of other rules and regulations, many of which Professor Graetz describes, ${ }^{82}$ that constrain the choices of employers in order to ensure a broader distribution of pension benefits. Because employer-sponsored plans are voluntary, however, the government may, in order to avoid plan terminations, hesitate to impose regulations that employers find burdensome, expensive, or inconsistent with their interests. Thus, as Professor Graetz argues, ${ }^{83}$ the minimum vesting standards, even as modified by the Tax Reform Act of 1986, fail to protect adequately the retirement security needs of workers who have intermittent or unconventional career paths. The government's rules for private pensions arguably are the consequence of the government's tempering retirement income goals in response to objections of employers.

In light of the inescapable tension that stems from reliance on voluntary private pensions, it might seem logical to substitute mandatory

so The employer might actually prefer not to cover younger workers if those workers would demand higher compensation, on an actuarial basis, if paid in deferred form. See Altman, supra note 8, at 473 (citing Wolk, Discrimination Rules for Qualified Retirement Plans: Good Intentions Confront Economic Reality, 70 VA. L. REv. 419,431 (1984)).

B1 Some regulation of private pensions would be required even if these pensions were not seen as a part of the national retirement income system. Even if the government saw itself only as a neutral arbiter, as it did in the beginning of the century, it would have to resolve disputes among the plan sponsor and the beneficiaries. See, e.g., McNevin v. Solvay Process Co., 32 A.D. 610, 53 N.Y.S. 98 (1898) (holding that a pension is a mere gratuity, and funds set aside for its payment are the sole property of the employer). But see Schofield v. Zion's Co-op. Mercantile Inst., 85 Utah 281, 39 P.2d 342 (1934) (holding that a pension constitutes a unilateral contract whose terms are fulfilled at retirement age, and therefore, payment of the promised amount must be made). Moreover, as part of the government's responsibility in determining the tax consequences of pension arrangements, some regulation would be required to ensure that the plans were bona fide.

${ }^{82}$ See Graetz, supra note 2, at 883-88.

${ }^{83}$ See id. at 885-87. 
private pensions or a fully adequate Social Security program. ${ }^{84}$ Under these alternatives, people would look to the mandatory program or programs for support after a designated age and after they cease to work. Voluntary private pension arrangements, together with their tax-favored treatment, would presumably cease to exist. ${ }^{85}$ Both of these alternative systems could be constructed to provide benefits that were more equitable in their distribution and generally more adequate in their levels than the current system. ${ }^{88}$ Nevertheless, these alternatives have serious weaknesses.

A nationally standardized retirement income system, whether in the form of Social Security alone or Social Security in combination with mandatory private pensions, is not flexible enough to meet the needs of our complicated economy: The system would be unable to respond rapidly to changing conditions. Furthermore, such a system would probably not permit targeted responses to the circumstances of different sectors of the economy. Today, employers can tailor the terms of their pension plans to the particular needs of their employees. Under a mandatory system, employers would be much more constrained. The basic system would be extremely costly, and, as mentioned above, favorable tax treatment for voluntary arrangements would probably be repealed. As a consequence, voluntary arrangements on top of the mandatory system would be prohibitively expensive. Moreover, because the mandatory system presumably would specify a benefit package, employers would most likely lack the flexibility to overcome the cost obstacles by changing the mandated priorities, making certain benefit ele-

B4 Some form of group pension seems imperative if adequate retirement income is to be achieved. Individual savings are unlikely to play more than a minor role in providing retirement income for most people. For a discussion of the reasons for the inadequacy of individual savings, see Altman, supra note 8, at 502 (citing Thompson, supra note 25 , at 1440 ).

${ }^{85}$ The current favorable tax treatment is justified on grounds of encouraging voluntary plans. See President's TAX Proposals, supra note 8, at 375 . If a mandatory system that met national retirement goals existed, the need to encourage supplemental voluntary plans would disappear. If there were a perceived need to supplement the mandatory program or programs, the system would be similar to the current hybrid system, but the mix of mandatory and voluntary components would be different. For a brief critique of that kind of change, see infra notes 89-92 and accompanying text. Moreover, it is probably impossible to tax large defined-benefit pension plans in a neutral manner, as a result of progressive tax rates and annual accounting years. See Altman, supra note 8, at 448-49. Therefore, if the favorable tax treatment were repealed, voluntary pension arrangements might be deterred by negative tax consequences as well.

${ }^{86}$ Professor Graetz appropriately defines the goal of national retirement income policies as the replacement of preretirement wages at a level sufficient to maintain the standard of living of at least low- and perhaps even moderate-income workers. See Graetz, supra note 2, at 855-56. 
ments more generous at the expense of other elements.

For example, some private pension plans offer employees the option of retiring earlier than the earliest retirement age under Social Security ${ }^{87}$ These plans may permit early retirees to receive larger benefits between that early retirement age and the age at which they begin to receive benefits under Social Security, and smaller benefits thereafter. In that way, the combined income from private pension benefits and Social Security benefits would remain constant throughout retirement. Under a program of mandatory pensions, employers would be unlikely to have the option to rearrange benefit levels and retirement ages because the government would then have difficulty ensuring that every plan in the country did indeed provide the federally mandated benefit. If employers either had no plans, or lacked the flexibility to so design their mandatory plans, older employees who were not able to maintain the demanding pace of particular jobs would be forced to turn to unemployment compensation, disability benefits, or means-tested welfare before satisfying the uniform, nationwide, preset retirement age. Moreover, some plans provide subsidized early retirement options. ${ }^{88}$ In the absence of this inducement, employers might be forced to rely on layoffs in a contracting industry.

Further, if Social Security were expanded to replace today's private pensions and if funding remained on a pay-as-you-go basis, ${ }^{\mathbf{8 9}}$ an important source of investment capital would be eliminated. If, instead, Social Security were advance-funded, serious questions would arise concerning who would control the assets and where they would be invested. Moreover, regardless of the resolution of those issues, difficult fiscal and other policy questions would arise as a result of the sheer magnitude of the fund reserves. ${ }^{90}$ Although mandatory private pensions would avoid some of these capital accumulation problems, they would have other shortcomings. For example, if benefits were not coordinated with Social Security, the combined benefits could result in overpensioning for some retirees and underpensioning for others. ${ }^{91}$ If benefit for-

87 See M. Meyer, Profile of Employee Benefits: 1981 Edition 29 (1981).

${ }^{88}$ See id. at 29-30.

${ }^{80}$ Social Security is financed on a current-funded or pay-as-you-go basis with only small contingency reserves. See TRUSTEES' REPORT, supra note 18 , at 17 .

90 For a discussion on a related question regarding the issues raised by a potentially large build-up in the reserves of Social Security in the 1990s, see Munnell \& Blais, Do We Want Large Social Security Surpluses?, New. ENG. Econ. Rev., Sept.Oct. 1984 , at 5 .

91 This can occur because Social Security has a progressive benefit formula. Private pension benefits that in combination with Social Security are fully adequate for high-income workers will be higher than full replacement for low-income workers. For a description of the Social Security benefit formula, see R. MEYERS, supra note 3, at 
mulae were integrated with Social Security, the system would be extremely complicated, imposing substantial administrative costs on even small employers. ${ }^{92}$

Reliance on voluntary private pensions permits flexibility in retirement arrangements and avoids the other shortcomings of a fully adequate retirement system that relies either on Social Security alone or on Social Security in combination with mandatory private pensions. Nevertheless, if the retirement income system is to rely on voluntary plans, the current distribution of retirement income, which Professor Graetz properly denounces, must be changed. The favorable tax treatment with respect to private pensions is intended to encourage employers to provide their workers with pensions that supplement Social Security. ${ }^{93}$ If this tax expenditure is to be justified, it must induce retirement benefits not only for the highest-income individuals, ${ }^{94}$ but also for those low- and moderate-income workers whose wages are not adequately replaced by Social Security and who are unable to save sufficient amounts on their own. ${ }^{95}$

Notwithstanding Professor Graetz's expressed concern, his proposal to impose a flat tax on pension funds does not alter the maldistribution of private pension benefits. Rather, by reducing the tax advantages associated with private pensions, his proposal would simply make private pensions somewhat less attractive as tax-savings devices. ${ }^{96}$ With

49-89, 147-68; Altman, supra note 8, at 477-78. For a discussion of the current integration rules, see $i d$. at $478-94$.

${ }^{82}$ More fundamentally, a requirement of mandatory pensions does not take into account other pressing needs. The government arguably should mandate a package of fringe benefits, just as it requires a minimum cash wage. The government action, however, should be comprehensive so that priorities and overall cost are carefully assessed.

83 The author has argued elsewhere that the goal of encouraging supplemental pensions was not the original purpose behind the favorable tax treatment. See Altman, supra note 8, at 446-50. Today, however, the purpose is clear. See President's TaX Proposals, supra note 8 , at 375.

84 Some argue that the retirement security of the highest-income people should only be important to the government as a method of gaining security for others. See, e.g., Graetz, supra note 2, at 857-58. But see President's TAX Proposals, supra note 8 , at 375 .

${ }^{25}$ Social Security provides inadequate benefits to maintain the standard of living of all workers except those at the lowest end of the income scale. See Altman, supra note 8 , at $476-77,494-96,501$.

${ }^{96}$ The primary tax advantage of qualified private pension plans is that the income of the funds held in trust is tax exempt. See Halperin, Interest in Disguise: Taxing the Time Value of Money, 95 YALE L.J. 506, 539 (1986). If the income were not held in these trust arrangements, but instead were held by the beneficiaries, the income would be taxed, like all other ordinary income, at each beneficiary's tax rate. To the extent the income held in trust is taxed, the tax advantage of this arrangement diminishes. Indeed, if the tax proposed by Professor Graetz is higher than the tax that would be imposed on the income held by lower-income employees, those employees would actually be better off, from a tax perspective, if they simply held the funds directly 
the reduction in tax advantages, fewer plans might exist, and those that did might provide smaller benefits. Nevertheless, those benefits presumably would continue to be distributed in the very manner he criticizes. Dedicating the revenue his proposal raises to increasing the benefits provided to low- and moderate-income workers under Social Security would improve the equity of the entire retirement income system. Such a dedicated tax, however, could inadvertently undermine the security of Social Security. The payroll tax used to finance Social Security ${ }^{\mathbf{9 7}}$ provides complete correspondence between those who pay the program's costs and those who receive the benefits. This complete correspondence, which presumably provides participants with a strong sense of entitlement, would be missing under Professor Graetz's tax. ${ }^{98}$ The introduction of this new, extraneous source of revenue, which lacks the complete correspondence of the payroll tax, could weaken the earned-right quality of Social Security, that is so important to the program's support.

Voluntary private pensions should be retained as an important part of the national system of providing retirement income. The distribution of voluntary plan benefits, however, should be made more equitable. ${ }^{9 \theta}$ The threat of plan terminations is no real threat if the equity of these arrangements is not increased. The trend of legislative changes has been in the direction of provisions designed to result in more benefits for low- and moderate-income workers. ${ }^{100}$ The opportunity for further reform exists. As a result of the large federal deficit and the size of

rather than indirectly through the pension trust.

${ }^{97}$ In addition to the payroll tax, small amounts of general revenue are used to finance Social Security. See supra note 28; infra note 98.

93 If Professor Graetz's tax were imposed on public pension plans, it would be imposed indirectly on some workers not covered under Social Security. The workers not covered under Social Security include federal civilian employees hired before January 1,1984 , and state and local employees working for employers who have opted not to participate in Social Security. See 42 U.S.C. \& 410 (1982 \& Supp. III 1985 \& West Supp. 1987). Moreover, not all participants in Social Security would be subject to Professor Graetz's tax. It should be noted that this lack of correspondence currently exists with respect to the revenue derived from the taxation of Social Security benefits, which are cycled back into the program. It is for that reason that some critics opposed the cycling back of revenues. See R. MYers, supra note 3 at 447-79.

${ }^{89}$ For a set of proposals that seek to achieve a more equitable distribution, see Altman, supra note 8, at 470-75, 494-500 (proposing modifications in the coverage, integration, and vesting rules).

100 See, e.g., Tax Reform Act of 1986, Pub. L. No. 99-514, § 1111-15, 100 Stat. 2085, 2435-54 (modifying the coverage, integration, vesting, and other rules concerned with equity); see also Employee Retirement Income Security Act of 1974, Pub. L. No. 93-406, 88 Stat 829 (codified at 29 U.S.C. $\$ \S 1001-1461$ (1982 \& Supp. III 1985 \& West Supp. 1987)) (adopting minimum standards for vesting and participation as well as other rules designed to increase the equitable distribution of private pension plan benefits). 
the tax expenditure associated with private pensions, Congress will probably continue to modify the private pension plan rules in its deficit and revenue packages. Although the revenue generated by distributional reforms is negligible, ${ }^{101}$ the Tax Reform Act of 1986 suggests that these kinds of reforms can be successfully included in legislation that has revenue (or in that case, revenue neutrality) as a principal concern.

In addition to criticizing the distribution of the retirement benefits of private plans, Professor Graetz is critical of the concomitant skewing of the tax savings. Some of the maldistribution would be corrected if the underlying retirement benefits were distributed more fairly. Nevertheless, even with a perfectly proportionate distribution of pension benefits to all those who fail to receive adequate benefits from Social Security, the tax advantages would still disproportionately favor high-income taxpayers. This result is to be expected from a progressive income tax system that makes use of tax expenditures to achieve public purposes. High-income workers who have higher income tax liabilities benefit disproportionately from exemptions, deferrals, and deductions.

The granting of tax benefits to higher-income taxpayers is a necessary byproduct of reliance on voluntary pensions. In order to retain voluntary employer-provided pensions as a significant part of the American retirement income system, favorable tax treatment must be preserved. ${ }^{102}$ While private employers have a variety of nontax reasons to provide retirement income for their employees, federal regulation of these arrangements undermines some of the nontax incentives and increases the cost. Employers cannot escape most other federal labor regulations, like minimum wage and maximum hour rules. In contrast, employers can discard deferred compensation. As a consequence, some incentive is necessary to make the labor regulation of voluntary pensions effective. As in the case of the payroll tax, the regressivity of the tax expenditure for private pensions should not cause the existing tax treatment to be altered. Rather, policymakers should ensure that, when viewed comprehensively, the federal tax burden retains a progressive tilt, notwithstanding the preferential tax treatment of voluntary private pensions.

101 Report of the Committee on Finance, S. Rep. No. 313, 99th Cong., 2d Sess. table III-2 (1986).

${ }^{102}$ Because of the difficulties involved in treating deferred compensation neutrally, removing the favorable tax treatment might actually result in penalizing that form of compensation. See Altman, supra note 8, at 448-50. 


\section{CONCLUSION}

Part I of this Response argued that the various programs and policies that comprise the retirement income system should be viewed comprehensively. When so analyzed, they demonstrate an overarching logic, despite the incremental and fragmented way in which the system has developed. Social Security ensures that all workers will receive a minimal level of retirement income at the ends of their working lives. Social Security, however, is inadequate by itself to provide complete retirement income for most workers. Decentralized, but highly regulated, voluntary private pensions, encouraged by tax subsidies, supplement Social Security. This hybrid pension system affords basic protection for workers while providing the important flexibility necessary in a complex economy.

Significant incremental reforms are necessary to make the system fairer, more adequate, and more secure. Dramatic overhauls or shifts in direction, however, are unwarranted and unwise. Modifications of the Social Security component should be made within the fundamental framework that was established at the program's inception and has served to keep the program politically popular and secure. This framework rests on the notion of an earned right. Reforms of the type suggested by Professor Graetz, while designed to improve the program, threaten to undermine its basic foundation. Better methods are available to address his tax equity concerns.

The voluntary private pension component of the system is in greater need of improvement. As Professor Graetz points out, the private pension component falls far short of the equity, adequacy, and security essential to a national retirement income system. ${ }^{103}$ Here too, though, the reforms should be in the direction of improving private pensions, not in the direction of undermining them, as Professor Graetz proposes.

Professor Graetz praises the pension changes contained in the Tax Reform Act of $1986 .{ }^{104}$ Congress should continue along the same lines to strengthen the requirements imposed on voluntary private pensions. The nation will then discover whether the retirement income system can become adequate and equitable for all workers and yet remain sufficiently flexibile to accommodate the needs of a complex economy. 